\title{
COMBINED EFFECT OF BEAUVERIA BASSIANA (BALS.) AND GAMMA IRRADIATION ON POTATO TUBER MOTH PHTHORIMAEA OPERCULELLA (ZELLER)
}

\author{
IBRAHIM,A.A. ${ }^{1}$; SANEYA R.M.FARAG ${ }^{1}$ and \\ SAMIA A.MOHAMED²
}

1. Plant Protection Research Institute, Agriculture Research Center, Dokki, Giza, Egypt.

2. Biological Application Department, Nuclear Research Center, Atomic Energy Authority, Cairo, Egypt.

(Manuscript received 24 March 2019)

\begin{abstract}
$\mathrm{T}$ he objective of this study was to show the susceptibility of different immature stages (eggs, larvae and pupae) of potato tuber moth Phthorimaea operculella (Zeller) (Lepidoptera: Glechiidae) to the entomopathogenic fungus (EPF) Beauveria bassiana, and the effect of irradiating full-grown male pupae of ph. operculella at sub-sterilizing doses 100 and $200 \mathrm{~Gy}$ of gamma irradiation (alone and in combination with $\mathrm{LC}_{50}$ of $B$. bassiana) on some biological aspects of resulting $F_{1}$ larvae, the results showed that, the EPF $B$. bassiana was pathogenic to all immature stages with $\mathrm{LC}_{50}$ values of $5.5 \times 10^{3}, 28.56$ and $1.1 \times 10^{5}$ conidia/ml, respectively, larvae were more susceptible to infection by $B$. bassiana than eggs and pupae. The percents of larval and pupal mortality were increased as the radiation doses increased while the percents of pupation and adult emergence were decreased as the radiation dose increased. Combination of gamma radiation and $B$. bassiana was more effective than either treatment of them alone.

Keywords: Beauveria bassiana, gamma-irradiation, pathogenicity, biological aspects, phthorimaea operculella.
\end{abstract}

\section{INTRODUCTION}

Potato tuber moth, Phthorimaea operculella (Zeller) (Lepidoptera: Glechiidae) is considered from the most serious pests of potatoes in Egypt as well as many other countries. It causes severe damage to potato tubers in the field and in the storage. Its main hosts are potato, tomato, and pepper.

The use of chemical insecticides to control potato tuber moth is associated with many problems of creating more resistance strains of the insect, the treated tubers become unvalid for human consumption due to persistence of residues in the tubers. This resulted in attempts to develop an integrated control program for potato tuber moth in the field and storage.

Entomopathogenic fungi such as Beauveria bassiana (Bals.) belong to the class of Hyphomycetes, are naturally occurring environmentally safe organisms, have a broad spectrum of hosts, can be mass produced easily, rapidly and economically (Rumbos and Athanassiou, 2017). They offer promise in the microbial control of certain economic crop pests (Jaronski, 2010). The use of irradiation techniques as a 
physical control method is cheap, safe and more reliable than chemical methods. Application of singular methods in insect control have limited success, so combining two or more control strategies with additive effects may increase program efficiency (Carpenter and Young, 1991). Recently, laboratory studies have revealed that semi sterility is compatible with other methods of pest control.

The objective of this study is to investigate the susceptibility of different immature stages (eggs, larvae and pupae) of Ph. operculella to entomopathogenic fungus $B$. bassiana and the effects of sub-sterilizing doses of gamm-irradiation alone and combined with $\mathrm{LC}_{50}$ concentration of the fungus $B$. bassiana on some biological aspects of $F_{1}$ larvae resulting from irradiated parental males.

\section{MATERIALS AND METHODS}

\section{Insect rearing:}

The tested insect, Ph. operculella (Lepidoptera: Gelechiidae) was obtained from the laboratory strain which reared (for five successive years) in the unit of stored product pests, Nuclear Research Center (NRC) Atomic Energy Authority, Egypt, as adults of both sexes were taken to mate and oviposite in chimney glass. The rearing technique was done according to Hemida (1976).

\section{Entomopathogenic fungus:}

Entomopathogenic fungus (EPF) used in the present study was B. bassiana (Bals.) conidia, obtained from fungal culture produced at the Bio-Insecticide Production Unit Plant Protection Research Institute, Dokki, Giza, Egypt.

\section{Susceptibility of immature stages of Ph. operculella to B. bassiana:}

Pathogenicity of the entomopathogenic fungus $B$. bassiana to immature stages (eggs, (larvae and pupae)males) of Ph. operculella was carried out in Petri dishes ( $9 \mathrm{~cm}$ diameter) containing filter paper according to the method of Dal Bello et al, 2001) different conidial concentrations ranged from $10^{4}$ to $10^{10}$ conidia/ml of $B$ .bassiana were used separately for each stage and applied to the filter paper by mini pump sprayer. Three replicates for each stage (10 individuals for each replicate) were carried out for each conidial concentration and three replicates without conidia as control. males of larvae and pupae were differentiated from females by method of Hemida (1976). The experiment was maintained at room temperature $25 \pm 2^{\circ} \mathrm{C}$ and relative humidity $60 \pm 5 \mathrm{RH}$. Dead individuals were recorded daily and infection confirmation by the fungus was done by collecting dead individuals and then transferred to sterilized Petri dish with moistened piece of cotton and incubated at $25^{\circ} \mathrm{C}$ unil fungal sporulation on the cadavers appear. 


\section{Effect of gamma-irradiation on some biological studies: \\ Experiment (1):}

This experiment was aimed to show, the effects of mating normal females with parental males $\left(\mathrm{P}_{1}\right)$ which irradiated as full grown pupae for 24-48hrs at two substerilizing doses (100 and 200 Gy) using (3500 Gamma cell irradiation units cobalt 60 source) located at the Middle Eastern Regional Radioisotope Centre for the Arab countries, Cairo (Egypt) with dose rate of $3.75 \mathrm{~Gy} / \mathrm{mint}$, on some biological aspects. The eggs laid by each female were collected, counted and incubated at $25 \pm 2{ }^{\circ} \mathrm{C}$ and $60 \pm 5 \%$ RH. Percentage of, hatchability, pupation and adult emergence were studied. Three replicates were carried out for each dose level and control.

\section{Experiment (2):}

Adult males irradiated at 100 and $200 \mathrm{~Gy}$ and normal were put with normal female in separate cages for mating and oviposition. Five replicates each contain one hundred eggs collected from each treatment were placed into small boxes containing seven potato tubers. The boxes were covered with tissue fixed with rubber band. Mature larvae ( $F_{1}$ larvae) which hatched from the eggs were treated with $L_{50}$ concentration of the EPF $B$. bassiana. Mortality percent of larvae, pupae and percent of adult emergence were calculated.

\section{Statistical analysis:}

Mortality percentages of all experiments were adjusted against that of control using (Abbott, 1925). Mortality data for concentrations ( $L C_{50}$ and $\left.L C_{90}\right)$, times $\left(L T_{50}\right.$ and $\mathrm{LT}_{90}$ ) and the slope of regression lines were calculated using probit analysis (finney, 1971). Data from biological studies were subjected to analysis of variance (ANOVA).

\section{RESULTS AND DISCUSSION}

\section{Susceptibility of immature stages of Ph. operculella to entomopathogenic} fungus $B$. bassiana:

Mortality percentages of different immature stages (eggs, larvae and pupae) of potato tuber moth Ph. operculella after treatment with different concentrations of the entomopathogenic fungus $B$. bassiana are showed in table (1). The obtained results showed that all concentrations tested of $B$. bassiana caused mortality to different immature stages of $P h$. operculella. The obtained data agree with Oliveria et al., (2010) who reported a high mortality of larvae and pupae of Ceratitis capitata at all concentrations of conidia of Metarhizium anisopliae and B.bassiana. The present results also show that mortality percentages of all tested stages seemed to be concentration dependent where the highest mortality percentage value recorded for the eggs, larvae and pupae were $96.7,99.98$ and $100 \%$, respectively at the highest concentrations $10^{10}, 10^{7}$, and $10^{9} \mathrm{conidia} / \mathrm{ml}$, respectively. The obtained results are in 
full agreement with (Li and Zhang, 2005) who concluded that, seven strains of $B$. bassiana were isolated from the cadavers of larvae of potato ( $P h$. operculella) and all of them were virulent to the larvae and the strain $\mathrm{Bb} 8001$ caused cumulative mortality of 70 and $86.7 \%$ as inoculated at $10^{5}$ and $10^{7}$ conidia $/ \mathrm{ml}$. the obtained results are in agree with El-Sinary and Rizk (2007) who tested two concentrations of the entomopathogenic fungus $B$. bassiana $10^{4}$ and $10^{8} \mathrm{spore} / \mathrm{ml}$ against the $4^{\text {th }}$ larval instar of the greater wax moth Galleria mellonella and found positive correlation between the fungal concentration and its lethality for the treated larvae. The obtained results also agree with Zheng et al., (2016) who reported that larval mortality of potato tuber mouth caused by infection of $M$. anisopliae (KMa0107strain) increased with increase of the concentration of conidial suspension.

Table 1. Mortality percentages of different immature stages (eggs, (larvae and pupae) males) of Phthorimaea operculella (Zeller) after treatment with different concentrations of Beauveria bassiana:

\begin{tabular}{|c|c|c|c|}
\hline \multirow{2}{*}{$\begin{array}{c}\text { Con. } \\
\text { Condia/ml }\end{array}$} & $\begin{array}{c}|c| \\
\text { Mean\% of eggs } \\
\text { mortality }\end{array}$ & $\begin{array}{c}\text { Mean\% of larval } \\
\text { mortality }\end{array}$ & $\begin{array}{c}\text { Mean\% of pupal } \\
\text { mortality }\end{array}$ \\
\hline $10^{4}$ & -- & 88 & -- \\
\hline $10^{5}$ & -- & 95 & -- \\
\hline $10^{6}$ & 70 & 96.5 & 71.4 \\
\hline $10^{7}$ & 83.3 & 99.98 & 85.6 \\
\hline $10^{8}$ & 90 & -- & 93.3 \\
\hline $10^{9}$ & 93.3 & -- & 100 \\
\hline $10^{10}$ & 96.7 & -- & 100 \\
\hline
\end{tabular}

The results also show that the larval stage of $P h$. operculella was more susceptible to fungal infection than eggs and pupae, this agree with Hafez et al. (1997) who reported that both first-and second instar larvae of $P h$.operculella were susceptible to $B$. bassiana than larvae in the third and fourth instar, and infection of pre-pupae and pupae resulted in marked decrease in the infection.

The obtained results also supported by Yuan et al., (2017) who evaluated six B. bassiana strains with potential for control of potato tuber worm Ph. operculella (Zeller) larvae and found that strain SD was the most virulent causing up to $98 \%$ mortality.

Regarding the toxicity values of EPF $B$. bassiana (Bals.) on different immature stages of Ph. operculella based on $\mathrm{LC}_{50}$, are indicated in table (2) and Fig (1). The data in the table indicated that, when larvae were treated with $B$. bassiana $\mathrm{LC}_{50}$ and $\mathrm{LC}_{90}$ values were equal to 28.56 and $5.1 \times 10^{4}$ conidia/ml, which are lower than those obtained for eggs $5.5 \times 10^{3}$ and $3.9 \times 10^{8}$ conidia/ml and those obtained for pupae $1.1 \times 10^{5}$ and $7.1 \times 10^{7}$ conidia $/ \mathrm{ml}$ respectively, so larvae are more susceptible to infection with $B$. bassiana than eggs and pupae, this may be due to nature of the 
cuticle and degree of sclerotization of the body surface among the three stages or may be due to mobility of larvae which may give them a great chance to be in contact with the fungus which is the main reason for infection. The results are in full agreement with Hajeck and St-leger (1994) who showed that, low pathogenicity of the fungi against many insect species was due to the nature of the cuticle in terms of its density, thickness and degree of sclerotization.

Table 2. Toxicity values of entomopathogenic fungus Beauveria bassiana against immature stages of potato tuber moth Phthorimaea operculella.

\begin{tabular}{|c|c|c|c|}
\hline Insect stage & $\begin{array}{c}\left(\mathbf{L C}_{\mathbf{5 0}}\right) \text { in } \\
\text { conidia/ml }\end{array}$ & $\begin{array}{c}\mathbf{( L C _ { 9 0 } )} \text { in } \\
\text { conidia/ml }\end{array}$ & Slope \pm S.E \\
\hline Eggs & $5.5 \times 10^{3}$ & $3.9 \times 10^{8}$ & $0.264 \pm 0.057$ \\
\hline $\begin{array}{c}\text { Larvae } \\
\text { (males) }\end{array}$ & 28.56 & $5.1 \times 10^{4}$ & $0.394 \pm 0.114$ \\
\hline $\begin{array}{c}\text { Pupae } \\
\text { (males) }\end{array}$ & $1.1 \times 10^{5}$ & $7.1 \times 10^{7}$ & $0.459 \pm 0.071$ \\
\hline
\end{tabular}

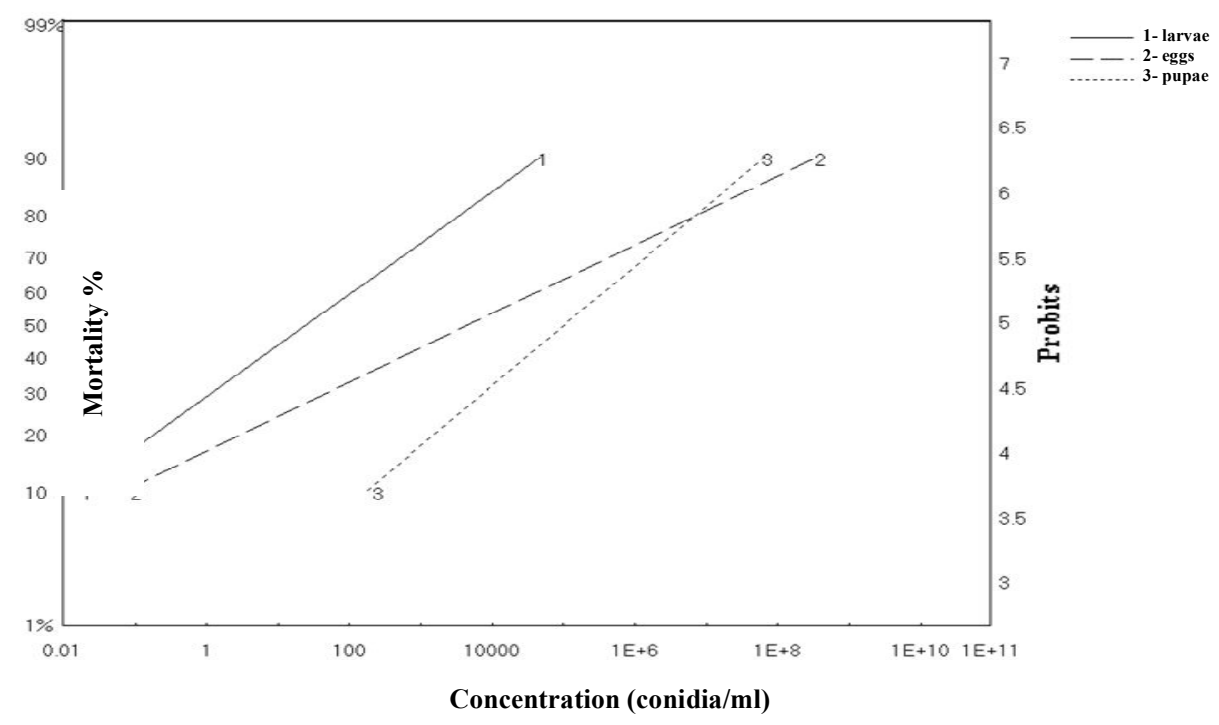

Fig. 1. LD-P lines of entomopathogenic fungus Beauveria bassiana against immature stages of potato tuber moth Phthorimaea operculella.

Regarding the median lethal time of $B$. bassiana to different immature stages of Ph. operculella data in table (3) show that, both $L T_{50}$ and $L T_{90}$ of the three stages (eggs, larvae and pupae) decrease as the initial concentration increases and the shortest $\mathrm{LT}_{50}$ value for larvae was, $1.2 \mathrm{~d}$ at the highest concentration $10^{7}$ conidial/ml, while the shortest $\mathrm{LT}_{50}$ value for eggs and pupae were, 1.13 and $1.48 \mathrm{~d}$, respectively at the highest concentration $10^{10}$ conidia/ml. these results agree with Zheng et al., (2016) who showed that the median lethal time of M.anisopliae to the potato tuber 
moth larvae differed with different concentrations and the shortest $\mathrm{LT}_{50}$ values was for the 2 nd instar, and the longest $\mathrm{LT}_{50}$ was for the $4^{\text {th }}$ instar.

Table 3. Lethal time (days) of different immature stages of Phthorimaea operculella after treatment with entomopathogenic fungus, Beauveria bassiana (Bals.) at different concentration under laboratory conditions.

\begin{tabular}{|c|c|c|c|}
\hline \multicolumn{5}{|c|}{ Eggs } \\
\hline Con.(conidia/ml) & $\mathrm{LT}_{50}$ & $\mathrm{LT}_{90}$ & Slope \pm S.E \\
\hline $10^{6}$ & 2.45 & 4.83 & $4.358 \pm 0.5255$ \\
\hline $10^{7}$ & 2.07 & 3.67 & $5.1829 \pm 0.5324$ \\
\hline $10^{8}$ & 1.82 & 3.19 & $5.2579 \pm 0.5004$ \\
\hline $10^{9}$ & 1.79 & 3.04 & $5.585 \pm 0.5177$ \\
\hline $10^{10}$ & 1.48 & 2.46 & $5.781 \pm 0.5188$ \\
\hline \multicolumn{5}{|c|}{ larvae (males) } \\
\hline Con.(conidia/ml) & $\mathrm{LT}_{50}$ & $\mathrm{LT}_{90}$ & Slope \pm S.E \\
\hline $10^{4}$ & 1.51 & 2.88 & $4.571 \pm 0.455$ \\
\hline $10^{5}$ & 1.43 & 2.74 & $4.544 \pm 0.393$ \\
\hline $10^{6}$ & 1.30 & 2.44 & $4.708 \pm 0.479$ \\
\hline $10^{7}$ & 1.21 & 2.05 & $5.607 \pm 0.534$ \\
\hline \multicolumn{5}{|c|}{ Pupae (males) } \\
\hline $10^{6}$ & $\mathrm{LT}_{50}$ & $\mathrm{LT}_{90}$ & Slope \pm S.E \\
\hline $10^{7}$ & 3.26 & 7.8 & $3.38 \pm 0.392$ \\
\hline $10^{8}$ & 2.91 & 6.1 & $3.989 \pm 0.415$ \\
\hline $10^{9}$ & 2.28 & 4.31 & $4.618 \pm 0.405$ \\
\hline $10^{10}$ & 1.49 & 2.72 & $4.947 \pm 0.412$ \\
\hline & 1.13 & 2.71 & $3.59 \pm 0.360$ \\
\hline
\end{tabular}

Effect of gamma irradiation:

Table 4. Effects of irradiating parental adult males of Phthorimaea operculella (resulting from irradiated full grown male pupae at sub-sterilizing doses) on percentage of adult emergence, pupal mortality, fecundity and hatchability

\begin{tabular}{|c|c|c|c|c|}
\hline Dose (Gy) & $\begin{array}{c}\text { \%adult } \\
\text { emergenc }\end{array}$ & $\begin{array}{c}\text { \%pupal } \\
\text { mortality }\end{array}$ & $\begin{array}{c}\text { average } \\
\text { number of } \\
\text { eggs/ } \\
\text { female } \pm \text { S.E }\end{array}$ & \%hatchability \\
\hline 0 & $98.0^{\mathrm{a}}$ & $2.0^{\mathrm{b}}$ & $88.68 \pm 3.64^{\mathrm{a}}$ & 89.89 \\
\hline 100 & $96.0^{\mathrm{a}}$ & $4.0^{\mathrm{b}}$ & $79.10 \pm 3.61^{\mathrm{a}}$ & 77.68 \\
\hline 200 & $89.0^{\mathrm{a}}$ & $11.0^{\mathrm{a}}$ & $62.90 \pm 3.86^{\mathrm{b}}$ & 60.99 \\
\hline
\end{tabular}

Data in table (4) Regarding, the irradiatiating full grown male pupae at 100 and $200 \mathrm{~Gy}$, there were slight decrease in the percent of adult emergence compared to control subsequently, the percentage of pupal mortality was slightly affected it was 4.0 and $11.0 \%$ respectively, compared to $2.0 \%$ in the control group. Concerning the effects on percent of fecundity and egg hatchability, the dose level 200Gy caused a 
significant decrease in both aspects, it was 62.90 and $60.99 \%$ respectively, compared to 88.68 egg and $89.89 \%$ in the control. This reduction in laid eggs per female probably occurred because of the lack of eupyrene transferred by irradiated males during mating. Similar reduction in the case of Pectinophora gossypiella was reported by Qureshi et al (1993), Al-Taweel and Ahmed (1997) on Ephestia figulilella, and Abass et al., (2017) on Spodoptera. littoralis, all reported that the egg laying and hatchability percentage decreased with increasing radiation doses. However Abd ElHamid (2004) exposed full grown male pupae of Agrotis ipsilon to three doses of gamma-irradiation (50, 100 and 150Gy), and found that the fecundity did not significantly differ from control at doses 50 and $100 \mathrm{~Gy}$, while it was significantly reduced at 150Gy. The reason for the reduction of fecundity and fertility was that the irradiated males were frequently failed to transfer sperm to females spermatheca and this failure resulted to reduced fecundity.

Table 5. Effect of irradiating parental adult males of Phthorimaea operculella on some biological aspects of ( $F_{1}$ larvae resulting from irradiated full grown male pupae) at sub-sterilizing dose.

\begin{tabular}{|c|c|c|c|c|}
\hline $\begin{array}{c}F_{1} \text { larvae } \\
\text { treatments }\end{array}$ & $\%$ pupation & $\begin{array}{c}\text { \%larval } \\
\text { mortality }\end{array}$ & $\begin{array}{c}\text { \%adult } \\
\text { emergence }\end{array}$ & $\begin{array}{l}\text { \%pupal } \\
\text { mortality }\end{array}$ \\
\hline $\mathrm{F}_{1} \mathrm{No}^{\mathrm{x} x \mathrm{~N}}$ ? control & $91.0^{a}$ & $9.0 \mathrm{c}$ & $84.3^{a}$ & $6.7^{b}$ \\
\hline $\mathrm{F}_{1} \mathrm{To}(100 \mathrm{~Gy}) \times \mathrm{N}$ ㅇ & $50.0^{b}$ & $50.0^{\mathrm{b}}$ & $41.1^{\mathrm{b}}$ & $8.9 a^{b}$ \\
\hline $\mathrm{F}_{1} \mathrm{To}^{\prime}(200 \mathrm{~Gy}) \times \mathrm{N}+$ & $24.0^{c}$ & $76.0^{\mathrm{a}}$ & $11.0^{c}$ & $13.0^{\mathrm{a}}$ \\
\hline
\end{tabular}

\section{Data were obtained from 100 eggs which replicated ten times.}

Date in table (5) summarized that larval and pupal mortalities were significantly increased as the radiation doses increased, while pupation and adult emergence were decreased as the radiation dose increased, it was 50 and $24 \%$ for pupation and 41.4 and $11 \%$ for adult emergence these mean that $F_{1}$ progeny were more sterile than parents at 100 and $200 \mathrm{~Gy}$, respectively compared to $84.3 \%$ in control. Our data are in agreement with El-Nagar et al., (1984) who reported that, irradiating full grown pupae of $A$. ipsilon at 5 or $10 \mathrm{krad}$ gamma radiation and crossed with unirradiated female. The $F_{1}$ progeny were more sterile than parents, and mortality among $F_{1}$ larvae was high and dose dependent, Qureshi et al. (1993) on Pectinophora gossypiella reported that, gamma radiation doses 50 and $200 \mathrm{~Gy}$ resulted in decreased adult emergence by increasing radiation doses and more deformed moths were recorded at dose $200 \mathrm{~Gy}$. 
Table 6. Effects of Gamma-irradiation (100 and 200Gy), with $\mathrm{LC}_{50}$ of the entomopathogenic fungus, Beauveria bassiana and joint action on some biological aspects of $F_{1}$ larvae of Phthorimaea operculella.

\begin{tabular}{|c|c|c|c|c|}
\hline${ }^{*} \mathrm{~F}_{1}$ Larvae treatments & $\begin{array}{c}* * \\
\% \text { pupation }\end{array}$ & $\begin{array}{l}\text { \%larval } \\
\text { mortality }\end{array}$ & $\begin{array}{c}* * * \\
\text { \%adult } \\
\text { emergence }\end{array}$ & $\begin{array}{l}\text { \%pupal } \\
\text { mortality }\end{array}$ \\
\hline$* \mathrm{~F}_{1}\left(\mathrm{~N} \sigma^{\top} \mathrm{xN}\right.$ N $)$ & $91.0^{a}$ & $9.0^{d}$ & $84.3^{a}$ & $6.7^{b}$ \\
\hline $\begin{array}{l}\mathrm{F}_{1} \mathrm{~L}\left(\mathrm{No}^{\top} \mathrm{xN} \text { \% }\right) \\
\text { B.bassiana }\end{array}$ & $55.0^{\mathrm{b}}$ & $45.0^{c}$ & $46.45^{b}$ & $8.55^{b}$ \\
\hline $\begin{array}{l}\mathrm{F}_{1} \mathrm{~L}(\mathrm{To} 100 \mathrm{~Gy} \\
\mathrm{xN}+)+\mathrm{LC}_{50} \text { B.bassiana }\end{array}$ & $29.1^{c}$ & $70.9^{b}$ & $18.89^{c}$ & $10.21^{\mathrm{ab}}$ \\
\hline $\begin{array}{l}\mathrm{F}_{1} \mathrm{~L}(\mathrm{To} 200 \mathrm{~Gy} \\
\mathrm{xN}+)+\mathrm{LC}_{50} \text { B. bassiana }\end{array}$ & $15.12^{\mathrm{d}}$ & $84.88^{a}$ & 00.00 & $15.12^{\mathrm{a}}$ \\
\hline
\end{tabular}

$* \mathrm{~F}_{1}$ larvae hatched from 100egg for each treatment, replicated 10 times.

$* *$ from hatched larvae

$* * *$ from hatched pupae

This study aimed to determine the susceptibility of $F_{1}$ larvae of Ph. operculella developed from irradiated full grown male pupae at 100 and 200Gy and crossed with normal female to $\mathrm{LC}_{50}$ concentration of $B$. bassiana. Table (6) illustrated the percent of resulting larvae transferred into pupae and adult emergence were 29.1 and $18.89 \%$ respectively at $100 \mathrm{~Gy}$, while in control treated with $\mathrm{LC}_{50}$ B. bassiana, these percentages were 55.0 and $46.45 \%$, respectively. The joint action effect of $200 \mathrm{~Gy}$ and B.bassiana showed that, the percentage of larvae that reached the pupal stage was $15.12 \%$, and no adult emerged from the pupae (all pupae died or prevented). While these percentage was $91.0 \%$ for pupae and $84.3 \%$ adult emergence in control treatment. These study was found to impair the development of Ph.operculella, i.e reduced percent larval that reached to pupal stage and adult emergence. Our data indicated that combination of gamma radiation and B.bassiana was more effective than either treatment alone. These results agree with El-Sinary and Rizk (2007) using B. bassiana at $10^{4}$ and $10^{8} \mathrm{spores} / \mathrm{ml}$ combined with gamma irradiation (50, 100 and $150 \mathrm{~Gy}$ ) against the $4^{\text {th }}$ instar larvae of Galleria melonella, the efficiency of B.bassiana increased, especially when the gamma-irradiation dose was increased, where no adults were produced with both of the fungal concentration and 150Gy gamma dose. Abd El-wahed (2011) also showed that the $\mathrm{LC}_{50}\left(10^{8}\right)$ of B.bassiana and M.anisopliae in combined with the $\mathrm{LD}_{50}$ (75Gy) of gamma irradiation against the $2^{\text {nd }}$ instar larvae of $A$ .ipsilon descending of irradiated parental males pupae, significantly increased the larval mortality and decreased the percentage of adult emergence, fecundity and fertility of A.ipsilon, El-Khawaga (2018) reported that the combined effect of gammairradiation and B.bassiana against the $2^{\text {nd }}$ instar larvae of G.mellonella, drastically decreased the number of eggs per mated female and percentage of egg hatchability 
and reported that the combined effect of the entomopathogenic fungi, and gammairradiation induced more remarkable effects as compared to each of them alone.

\section{CONCLUSION}

In order to complete the pest control management we can used the $\mathrm{LC}_{90}$ of $B$. bassiana to reduce infestation by Ph. operculella in the field and irradiated the potato bulk with the sub-sterilize dose 200Gy which have effect on the insect and no effect on germination of potato crop.

\section{REFERENCES}

1. Abass, A.A., Salem, H.M.; Abd-El-Hamid, N.A.; Gabarty, A. and Embaby, D.N. 2017. Effect of Gamma-irradiation on the biological activity of the cotton leaf worm, Spodoptera littoralis (Boid.). J.Nucl.Tech.Appli. Sci.5(1): 19-26.

2. Abbott, W.S. 1925. A method of computing the effectiveness of an insecticide. J.Econ. Entomol. 18: 265-267.

3. AbdEl-Hamid, W.A. 2004. Effect of gamma-irradiation on certain biological and physiological aspects of black cut worm, Agrotis ipsilon (Hufn). M.Sc. Thesis. Fac. Agric.Cairo Univ.

4. Abd El-Wahed, A.G.A. 2011. Combined effect of gamma radiation and some fungal control agents on the greasy cut-worm, Agrotis ipsilon (Huf.) Doctoral dissertation, Faculty of Science, Al-Azhar university.

5. Al-Taweel, A.A; Ahmed, M.S.H.; Waheed, A.K. and Nasser, M.J. 1997. Inherited sterility in progeny of gamma-irradiation of rqisin moth, Ephestia figulilella (Grey) (Lepidoptera: Pyralidae). Dirasta Agric. Sci. 24:128-134.

6. Carpenter, J.E and Young, I.R. 1991. Interaction of inherited sterility and insecticide resistance in the fall army worm (Lepidoptera: Noctuidae). J. Econ. Entomol. 84: 25-27.

7. Dal Bello G., Padin, S.Lopezlastera, C.and Fabrizio, M. 2001. Laboratory evaluation of chemical-biological control of the rice weevil (Sitophilus oryzae L.) in stored grains. Journal of stored products research, 37, 77-84.

8. El-Khawaga, O.E. 2018. Effect of gamma irradiation and some fungi on the greater wax moth, G.mellonella (L)M.Sc, Thesis Fac. Sci. Banha Univ.

9. El-nagar, S.E.; Megahed, M.M.; Sallam, H.A. and Ibrahim, S.M. 1984. Inherited sterility among Agrotis ipsilon laboratory population exposed to gamma irradiation. Insect Sci. \& its Appl. 5: 501-503.

10. El-Sinary, N.H. and Rizk, S.A. 2007. Entomopathogenic Fungus Beauveria bassiana (Bals) and gamma irradiation efficiency against the greater wax moth Galleria mellonella (L.) American-Eurasian J.Scientific Rese, 2(1): 13-18. 
11. Finney, D.J. 1971. Probit analysis, statistical treatment of the sigmoid response curve. Cambridge Univ. press, Cambridge.

12. Hafez, M.; Zaki, F.N.; Moursy A.and Sabbour, M. 1997. Biological effects of the entomopathogenic fungus Beauveria bassiana on the potato tuber moth, Phthorimaea operculella (Zeller). J. Pest Sci, 70 (80): 158-159.

13. Hajeck, A.E. and St-Leger, R.J. 1994. Interaction between fungal pathogens and insect hosts. Annu. Rev. Entomol. 39: 293-322.

14. Hemida, E.A. 1976. Biological and physical studies on Pthorimaea operculella (Zeller) (Lepidoptera: Gelechiidae), M.SC. Thesis, Fac. Sci. Ain Shams Univ., Egypt.

15. Jaronski, S.T. 2010. Ecological factors in the in undative use of fungal entomopathogens. Biocontrol, 55: 159-185.

16. Li, Z. Y. and Zhang, Q.W. 2005. Relative virulence of iosolates of Beauveria bassiana to the potato tuber moth Phthorimaea operculella and their biological compatibility with ten insecticides. Plant protection, 31 (3): 57-61.

17. Olivera, F.O.de; Batista, J.deL.; Malaquos, J.B.; Almeida, D.M. and Oliveria, R.de 2010. Determination of the median lethal concentration $\left(L C_{50}\right)$ of mycoinsecticides for the control of Ceratitis capitata (Diptera: Tephritidae) Revista Colombiana de Entomologia. 36.2: 213-216.

18. Qureshi, Z.A., Ahmed, N. and Hussein, T. 1993. Rearing and gamma radiation effects on mature pupae of P.gossypiella and their $F_{1}$ progeny, Proc. Final Res. Co-ordination meeting Phoenix, AZ. 9-13 Sept. IAEA, P 57-71.

19. Rumbos, C.I. and Athanassiou, C.G. 2017. Use of entomopathogenic fungi for the control of stored-product insects: can fungi protect durable commodities? Journal of pest science 90 (3): 839-854.

20. Yuan, H.G.; Lei, Z.R.; Rondon, S. and Goa, Y.L. 2017. Potential of a strain Beauveria bassiana (Hypocreales: Cordycipitaceae) for the control of the potato tuber worm Phthorimaea operculella (Zeller) Inter. J. of pest. Manag; 63 (4): 352-34.

21. Zheng Y.; Song, S.J.; Chen; B.; Xiao Gaunli, Y.L; Luo, C.P. and Li, Z.Y. 2016. The infection effect of Metarhizium anisopliae KMa 0107 against the larvae of potato tuber moth, Phthorimaea operculella (Zeller).J. of Yunnan Agric. Univ., 31 (6) 999-1005. 


\title{
التأثير المشترك لفطر Beauveria bassiana و أشعة جامـا على فر اشة درنات البطاطس
}

\author{
أحمد علدى ابر اهيم1 ، سنيه رشاد فرج1 ، ساميه عبد الواحد محمد2 \\ 1 معهد بحوث وقاية النباتات ـ مركز البحوث الزراعية ـ دقى- جيزة- مصر.

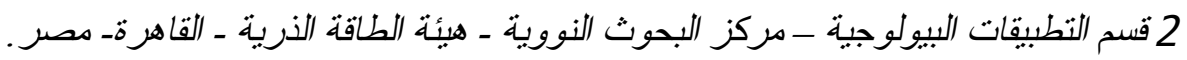

أجرى البحث بهدف در اسة ددى حساسية الأطو ار الغير ناضجة (البيض، الير قات ، الـذارى)

لفر اثة درنات البطاطس Phthorimaea operculella للفطر الممرض للحشرات Beauveria bassiana

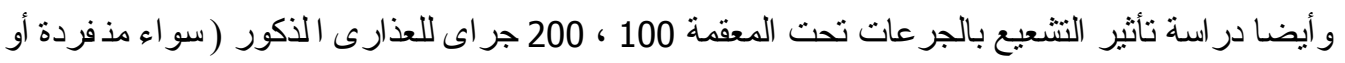

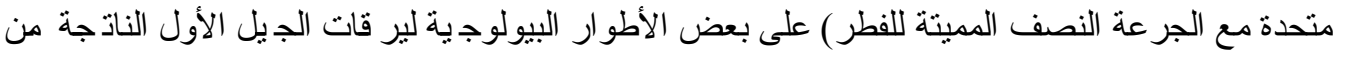

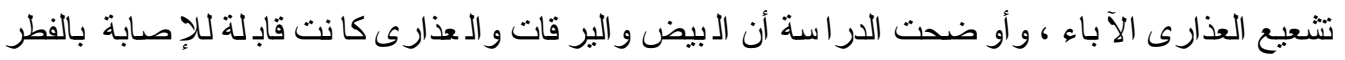

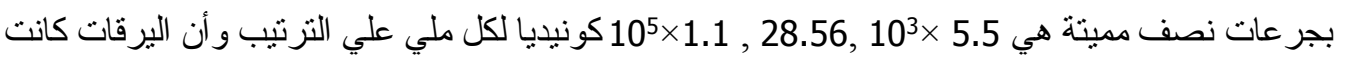

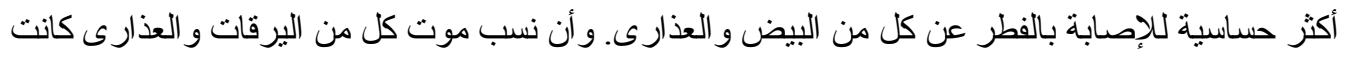

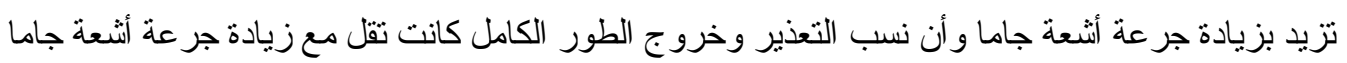

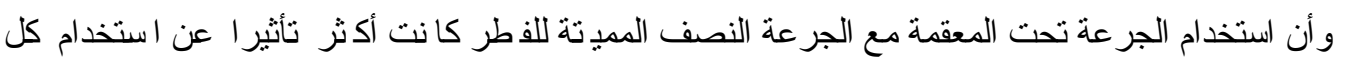
معاملة منهم علي حدة. 
